\title{
Duygusal Emek Kişilik Özellikleri ile İlişkili mi? Otel Çalışanları Üzerine Bir Araştırma
}

\section{Is Emotional Labor Related With Personality Traits? A Research on Hotel Employees}

\author{
Dr. Öğr. Üyesi Yasin KELEŞ ${ }^{1}$
}

\begin{abstract}
Özet
$\mathrm{Bu}$ araştırmanın amacı, otel çalışanlarının kişilik özelliklerinin sergiledikleri duygusal emek ile ilişkisini belirleyebilmektedir. Bu kapsamda Bodrum'da faaliyet gösteren beş yıldızlı otel işletmelerindeki 402 çalışana anket uygulanmıştır. Çalışanların kişilik özellikleri beş faktör kişilik envanteri çerçevesinde betimlenmiştir. Buna göre en yüksek ortalama, gelişime açıklık boyutunda, en düşük ortalama ise nevrotiklik boyutunda elde edilmiştir. Çalışanların sergiledikleri duygusal emek ise duygusal çelişki ve duygusal çaba olmak üzere iki boyutta ölçülmüştür. Otel çalışanlarının duygusal çabaları duygusal çelişki boyutuna göre daha yüksek hesaplanmıştır. Araştırma bulgularına göre, duygusal çelişki ile kişiliğin öz disiplin ve uyumluluk boyutları ile arasında negatif yönlü orta kuvvette, dışadönüklük boyutu ile negatif yönlü düşük kuvvette; nevrotiklik ile de pozitif yönlü düşük kuvvete anlamlı ilişkiler tespit edilmiştir. Duygusal çaba ile kişiliği özdisiplin, uyumluluk, gelişime açıklık ve nevrotiklik boyutları arasında ise pozitif yönlü düşük kuvvette anlamlı ilişkiler tespit edilmiş̧ir. Yapılan basit doğrusal regresyon analizleri, duygusal çelişkiyi özellikle özdisiplin ve uyumluluk özelliklerinin azalttığını; nevrotikliğin ise arttırdığını göstermektedir.
\end{abstract}

Anahtar Kelimeler: Kişilik özellikleri, duygusal emek, otel çalışanları, turizm

Makale Türü: Araştırma makalesi

\begin{abstract}
The purpose of this study is to determine the relationship between the personality traits and the emotional labor of the hotel employees. In this context, 402 employees in five star hotels operating in Bodrum were surveyed. The personality traits of the employees are described within the framework of the five factor personality inventory. According to this, the highest mean was calculated in the dimension of openness to development and the lowest mean in the neuroticism dimension. Emotional effort displayed by the employees was measured in two dimensions: emotional conflict and emotional effort. Emotional efforts of hotel employees were calculated higher than the emotional conflict dimension. According to the findings of the study, emotional conflict has significant medium-negative correlation with conscientiousness and agreeableness dimensions of personality; low negative correlation with extraversion and low positive correlation with neuroticism. Significant low-positive relationships were found between emotional effort and conscientiousness, agreeableness, openness and neuroticism dimensions of personality. Simple linear regression analyzes show that emotional conflict decreases especially conscientiousness and agreeableness as neuroticism increases.
\end{abstract}

Keywords: Personality traits, emotional labor, hotel employers, tourism

Paper Type: Research paper

${ }^{1}$ Ondokuz Mayıs Üniversitesi, Turizm Fakültesi, yasin.keles@omu.edu.tr, Orcid ID: https://orcid.org/ 0000-0002-6879-448X 


\section{Giriş}

Yapısı gereği emeğin yoğun olduğu turizm sektöründe, çalışanların müşterilere yönelik sergilediği duygular önemli bir yer tutmaktadır. Bir destinasyonda ziyaret edilen alanların yanında verilen hizmetin niteliği de müşteriler açısından önemli olarak değerlendirilmektedir. Hatta hizmetin niteliği, destinasyonların doğal ve kültürel turistik çekiciliklerinin önüne geçebilmektedir. Bu açıdan ticari bir değeri olan duyguların, hizmet verenler tarafından yönetilmesi ve müşteriye uygun biçime dönüştürülerek sunulması gerekmektedir. Bu süreç, duygusal emek olarak nitelendirilmektedir.

Duygusal emek, ilgili alanyazında üzerinde oldukça durulan; sebepleri ve sonuçları üzerine fazlaca çalışılan bir konu halini almıştır. Yapılan araştırmaların sahası, özelliği gereği hizmet sektörüne yönelmektedir (Hochschild, 2003: 244-251). Hizmet sektörünün içinde önemli bir yeri olan turizmde ise en fazla çalışanın olduğu çalışma alanı, konaklama işletmeleridir. Müşteri ile etkileşim sayısı ve sıklığı dikkate alındığında, otel çalışanlarının sergiledikleri duygusal emeğin müşteri tatmininde oldukça önemli bir belirleyici olduğu söylenebilir. Duygusal emek gösterimlerinin temel sebepleri arasında örgütsel ve bireysel faktörler yer almaktadır. Örgütsel faktörler yönetici davranışlarına ve çalışma ortamına odaklanırken; bireysel faktörler ise bireyin duygusal ve ruhsal yönlerine yönelmektedir. $\mathrm{Bu}$ noktada duygusal emek gösterimlerinin çalışanların kişilik özellikleri ile ne kadar ilgili olup olmadığını ortaya koymak, istihdam edilecek çalışanların niteliğini belirleyebilmek açısından önemlidir. Bu araştırmada duygusal emeğin kişilik özellikleri ile ilişkisi incelenmiştir.

\section{Duygusal Emek Ve Kişilik Özellikleri Arasındaki İlişkiler}

Duygusal emek, kişilerarası iş süreçlerinde örgütün istediği duyguları yansıtmada gerekli olan çaba, planlama ve kontrol olarak tanımlanmaktadır (Morris ve Feldman, 1996: 987). Duygusal emek Hochschild (1983) ve Frandey (2000) tarafindan, yüzeysel ve derin davranış olarak ele alınırken, Asforth ve Humprey (1993), bu boyutlara doğal davranış boyutunu da eklemiştir. Morris ve Feldman (1996), başka bir bakış açısıyla duygusal emeği duygusal davranış gösterimindeki sıklık, davranış kurallarına gösterilen dikkat, sergilenmesi gereken duyguların çeşitliliği ve duygusal çelişki boyutları ile değerlendirmiştir. Bazı araştırmalarda ise gerçekte hissedilen duygular (doğal davranış) ile yansıtılması beklenen duyguların (yüzeysel davranış) çatışması sonucu oluşan duygusal çelişki ayrı bir boyut olarak ele alınmış; örgütün belirlediği duygusal gösterim kurallarına uyma çabası ise duygusal çaba olarak değerlendirilmiş ve derin davranış ile ilişkilendirilmiştir. (Chu ve Murrman, 2006; Kurml ve Geddes, 2000). Bu araştırmada duygusal emek, duygusal çelişki ve duygusal çaba olarak ele alınmıştır.

Turizm sektöründe çalışanların sergiledikleri duygular, sunulan hizmetin önemli bir parçasını oluşturmaktadır. Etkileşim sıklığı ve duyguların insanların bir parçası ve sosyal etkileşimle çok yakından bağlantılı olması (Sekerka ve Fredrickson, 2010: 531), turizm sektörü için duygu yönetimini önemli bir konu haline getirmiştir. Morris ve Feldman (1996: 988) da duygusal davranış kurallarının sergilenmesinin, hizmet sektörü çalışanlarının yaptıkları işlerin önemli bir kısmını oluşturduğunu belirtmektedir. Olumlu duygusal ifadelerin takınılması, olumlu ilişkilerin sürdürülmesi ve olumsuz duygusal ifadelerin bastırılması, müşteri tatmini açısından çok önemli görülmektedir (Grandey, 2000: 95). Bu durumda, turizm sektöründe duygusal emeğin hizmet kalitesinde belirleyici olması, işletme yöneticilerini, çalışanların duygularını kontrol edebilmeleri ve örgüt tarafından beklenen duyguları yansıtabilmelerine yönelik girişimlerde bulunmaya zorlamaktadır (Keleş, 2014: 75). Hatta mevcut çalışanlara yönelik girişimlerin yanı sıra, işe alma aşamasında örgüt tarafından beklenen duyguları yansıtabilecek işgören seçimi de önemli bir konu olarak değerlendirilebilir. İşgören seçiminde alanla ilgili eğitim, tecrübe ve birtakım teknik 
özelliklerin yanında, duygusal emeğin önemli olduğu alanlarda da farklı beklentiler devreye girebilmektedir.

Bireylerin sergiledikleri duygusal emeği etkileyen faktörler gerek örgütsel gerekse bireysel kaynaklı olabilmektedir. Duygusal emek gösterimlerinin, duygu gösterim kuralları, etkileşim özellikleri, olumlu ve olumsuz duygular, örgüt içi ilişkiler ve örgütsel faktörlerin yanı sıra bireysel özellikler ve kişilik özellikleri kaynaklı olduğu söylenebilir (Keleş, 2014). $\mathrm{Bu}$ yarg1, duygusal olaylar kuramı ile de açıklanabilir. Duygusal olaylar kuramına göre (Weiss ve Cropanzano 1996), bireylerin duygusal tepkilerinin gerekçelerinden biri de kişilik özellikleridir.

Kişilik, insanların karşı karşıya kaldığı durumlara gösterdiği tepkileri ve diğer insanlarla iletişimlerini belirleyen duygusal ve zihinsel kalıpların bütünü olarak ifade edilmektedir (Robbins, DeCenzo ve Coulter, 2013: 227). Aynı zamanda kişilik, bireyi diğerlerinden ayıran nispeten kalıcı özellikler ve eğilimler (Vecchio, 1991: 85) olarak tanımlanabilmektedir. Smith vd.'ne (2012) göre kişilik, bir bireyin fiziksel ve sosyal çevresiyle etkileşme biçimini açıklayan düşünce, duygu ve davranışın ayırt edici ve karakteristik örüntüleridir. Özellikle müşteri ile iletişimin yoğun olduğu turizm sektöründe, çalışanların kişilik özellikleri önemli bir boyut kazanmaktadır.

Konu ile ilgili literatürde kişiliği ölçmeye çalışan birçok yaklaşım bulunmakla birlikte, üzerinde en çok fikir birliğine varılan yöntemlerden biri "beş faktör kişilik" özellikleridir. Beş faktör kişilik özellikleri, uyumluluk, dışadönüklük, sorumluluk, gelişime açılılı ve nevrotiklik (Barrick ve Mount, 2003; Costa ve McCrae 1995, Costa, McCrae ve Dye, 1991, McCrae ve Costa,1991; Robbins vd., 2013) olmak üzere beş boyuttan oluşmaktadır. Bireylerde, söz konusu beş boyutun hepsinden özellikler yer alabilmektedir (Ellis, Abrams ve Abrams, 2009).

Beş faktör kişilik modeline göre, olumlu duygusal özelliklerin dışadönüklerde fazla olduğu ve doğal olarak diğer insanlardan daha doğal oldukları ifade edilmektedir (Watson ve Clark, 1997). Dişadönüklük bireyler diğer bireylere nazaran ruh hallerini daha iyi düzenleyebilmektedirler (McAdams, 2008). Dişadönük bireyler, neşeli, konuşkan, sosyal, kendine güvenen ve toplum içinde bulunmaktan keyif alan özellikler sergilemektedir (Costa vd., 1991, Schultz ve Schultz, 2009). Bu husus da, dışadönüklerin duygusal emeğin doğal ve yüzeysel duygularının bir arada değerlendirmesini içeren duygusal çelişkiyi çok fazla yaşamayacaklarına işaret etmektedir. Yapılan araştırmalarda dışadönüklerin duygusal uyumsuzluğu daha az yaşayacakları ve duygusal çaba gösterimlerinde zorlanmayacakları ifade edilmektedir (Barrick ve Mount 2000; Judge vd. 2009).

Özdisiplin boyutu özellikleri yüksek olan kişiler hırslı ve başarı yönelimli iken, düşük olanlar ise plansız ve disiplinsiz olarak değerlendirilmektedir (Costa ve McCrae, 1995). Bu özelliği yüksek olan bireyler güvenilir, düzenli ve sorumluluğunu bilen kişilerdir (Costa vd., 1991). Bu durumda özdisiplin özelliği yüksek olan bireylerin duygusal emeğin duygusal çaba boyutundaki rolleri daha çok yerine getirebileceği ve duygusal çelişkiyi daha az yaşayabileceği muhtemeldir. Başka bir ifade ile özdisiplin özelliği, duygusal çaba sergileme eğilimini kuvvetlendirecektir.

Nevrotiklik boyutu, depresif, gergin, kaygıl1, huzursuz, sabırsız ve üzgün olma, sıklıkla duygusal iniş çıkışlar yaşama gibi kişilik özelliklerini kapsamaktadır (BenetMartinez ve John, 1998; Costa vd., 1991). Nevrotiklik, duygusal sıkıntıya eşlik eden rahatsız edici düşünceleri ve davranışları da içermektedir (McCrae ve Costa, 1987). Bu durumda müşteriler ile yoğun iletişim gerektiren turizm sektöründe nevrotik bireylerin çalışmasının ne 
kadar uygun olacağı tartışma götürmez bir durumdur. Konuya duygusal emek açısından bakıldığında, nevrotik bireylerin duygusal çelişkiyi daha çok yaşayabileceklerini söylemek mümkündür.

Uyumluluk, güvenilir, yardımsever, doğruluk, iyi huyluluk özellikleri ile birlikte anılmaktadır (Costa vd., 1991; Schultz ve Schultz, 2009). Uyumluluk boyutundaki özellikleri yüksek olan bireyler diğer insanları seven, verici ve merhametli bireyler olarak değerlendirilmektedir (Somer vd., 2002). Duygusal emeğin duygusal çaba boyutu, başkalarının duygularını anlayabilmeyi de içerdiğinden, bu özelliği yüksek olan bireylerin daha az duygusal çelişki yaşayacaklarını ve daha fazla duygusal çaba harcayacaklarını ifade etmek mümkündür.

Gelişime Açıklık boyutundaki özellikleri yüksek olan bireyler ilgili, meraklı, yeniliklere açık, bağımsız, yaratıı ve değişime açık özellikler sergilemektedirler (Costa vd., 1991; Doğan, 2013; Schultz ve Schultz, 2009). Bu özellikleri yüksek olan bireylerin de duygusal çelişkiyi daha az yaşayacaklarını söylemek yerinde olacaktır. Araştırmanın devam eden bölümünde duygusal emek ve kişilik özellikleri arasındaki ilişkiler üzerinde duran araştırmalara üzerinde durulmuştur

\section{2. İlgili Araştırmalar}

Özellikle insan unsurunun ön planda olduğu işlerde, örgüt içi iletişim ve müşteri iletişimi esnasında duyguların kontrol edilmesi ve yönlendirilmesi oldukça önemlidir (Keleş, 2014). $\mathrm{Bu}$ noktada duygusal emek otel işletmeleri için büyük önem arz etmekte; çalışanlardan belirlenen duygusal davranış kurallarına uyması beklenmektedir. Daha önce de ifade edildiği üzere duygusal emeği yönlendiren birçok örgütsel faktör mevcut olmakla birlikte, kişilik özellikleri de duygusal emeğe yön verebilmektedir.

Duygusal emeğin kişilik özellikleri ile ilişkisine yönelik ilgili alanyazında bazı araştırmalarla karşılaşmak mümkündür. Örneğin, Sohn ve Lee'nin (2012) kişilik özellikleri ile duygusal emek ilişkisini inceledikleri araştırmada derin davranışla dişadönüklük, açıklık, uyumluluk ve sorumluluk arasında pozitif yönlü ilişkiler tespit edilirken, yüzeysel davranışla uyumluluk arasında pozitif yönlü, dürüstlük arasında negatif yönlü ilişkiler bulunmuştur. Deniz'in (2016) çalışmasında da gelişime açıklığın duygusal çelişkiyi olumlu yönde etkilediği tespit edilmiştir. Yine Kim (2008)'in araştırmasında, dışadönüklüğün duygusal çaba ile ilişkili olduğu sonuçlarına ulaşılmıştır. Eighie vd. 'nin (2012) çalışmasında dışadönüklüğün yüzeysel davranışı pozitif yönde, derin davranışı ise negatif yönde etkilediği ortaya konulmuş ve bu durum; içedönük bireylerin daha az sosyal olduklarına, yüz yüze iletişimi uzun süre devam ettirmek istemeyeceklerine dayandırılmıştır. Tan vd.'nin (2003) çalışmasında da hizmet sektöründe dışadönük bireylerin içedönüklere göre daha fazla pozitif duygu sergileme eğilimli oldukları belirtilmiştir. Aslan ve Arı'nın (2018) çalışmasında da dışadönüklük, özdisiplin ve uyumluluk özellikleri yüksek bireylerin doğal duygu gösterimlerinin de arttığı yönünde sonuçlara ulaşılmıştır.

Diefendorff vd. 'nin (2005) çalışmasında, yüzeysel davranış ile dışa dönüklük arasında negatif, nevrotiklik ve olumsuz davranış kuralları arasında pozitif ilişkiler gözlenirken; derin davranışla etkileşim sıklığı ve olumlu davranış kuralları arasında pozitif, etkileşim rutinliği arasında negatif ilişkiler tespit edilmiştir. Ayrıca, derin davranışla pozitif ve negatif duygular arasında anlamlı ilişkiler tespit edilmiştir. Gürsoy, Boylu ve Avcı'nın (2011) yaptıkları araştırmada ise duygusal emek ile nevrotiklik arasında pozitif iliş̧kiler bulunmuştur. Begenirbaş ve Can Yalçın (2012) ile Basım vd.'nin (2013) araştırmasında da nevrotiklik ile yüzeysel davranış arasında pozitif bir ilişki bulunmuştur. Yine Eighie vd., (2012), nevrotikliğin derin davranışı negatif yönde etkilediği sonucuna ulaşmıştır. Buna ek 
olarak alanyazındaki birçok araştırma (Brotheridge ve Grandey 2002; Deniz, 2016; Karatepe ve Aleshinloye, 2009; Liu vd. 2004; Spector vd,. 2000) nevrotikliğin duygusal çelişki ile ilişkisine işaret etmektedir. Söz konusu araştırma sonuçları, nevrotikliğin duygusal çabayı azalttığı, duygusal çelişkiyi ve/veya yüzeysel davranışı arttırdığını göstermektedir.

\section{Araştırmanın Amacı ve Önemi}

İlgili araştırmalarda da yer verildiği üzere, kişilik özelliklerinin duygusal emek gösterimlerinde belirleyici olabileceği anlaşılmaktadır. $\mathrm{Bu}$ araştırmanın amacı, otel çalışanlarının kişilik özellikleri ile duygusal emek gösterimleri arasındaki ilişkiyi belirleyebilmektir. $\mathrm{Bu}$ doğrultuda araştırmada şu sorulara cevap aranmıştır:

- Otel çalışanlarının gösterdikleri duygusal çaba, kişilik özellikleri ile ilişkili midir?

- Otel çalışanlarının duygusal çelişki gösterimleri, kişilik özellikleri ile ilişkili midir

Araştırma sorularının betimlenmesi, otel işletmeleri için personel istihdamı konusunda da yön verebilecek nitelikler taşımaktadır. Özellikle hizmetin önem taşıdığ turizm sektöründe/otelcilik sektöründe, duygusal emeği örgütün beklentileri doğrultusunda sergileyebilecek bireylerin istihdam edilmesi, çalışma yaşamına geçmeden birçok sorunun önüne geçebilecektir. Daha önceki çalışmalarda da belirtildiği üzere (Keleş ve Tuna, 2018), derin davranışın (bu araştırmaya göre duygusal çabanın) çalışanlar açısından olumlu sonuçlar doğurduğu, yüzeysel davranışın ve/veya duygusal çelişkinin ise olumsuz sonuçlar ortaya çıkardığı bilinmektedir. Bu noktada özellikle, duygusal çabayı ve duygusal çelişkiyi tetikleyen kişilik özelliklerinin belirlenmesi, otel yöneticilerine çalışanların işe alma süreçlerinde fikir verebilecektir.

\section{Araştırmanın Yöntemi}

Araştırma deseni nicel olup, veriler anket aracılı̆̆ıyla elde edilmiştir. Antalya'nın Belek bölgesinde faaliyet gösteren beş yıldızlı otel işletmelerinde çalışan 402 kişiye anket uygulanmıştır. Kişilik özelliklerini belirleyebilmek amacıyla ilgili alanyazında sıklıkla kullanılan, John, Donahue ve Kentle (1991) tarafindan geliştirilen, dışadönüklük, uyumluluk, gelişime açıklık, nevrotiklik ve öz disiplin olmak üzere beş boyutlu ve 44 ifadeden oluşan beş faktör kişilik envanterinden yararlanılmıştır. Duygusal emek için ise duygusal çelişki ve duygusal çaba boyutlarını içeren Chu ve Murmann (2006) tarafından geliştirilen, Avcı ve Boylu (2010) tarafından Türkçe'ye uyarlanan 13 soruluk oluşan ölçekten yararlanılmıştır. Aynı zamanda katılımcıların demografik özelliklerini betimleyen sorulara yer verilmiştir. Elde edilen veriler istatistik paket programı aracılığıyla, ortalama ve standart sapma değerleri ile betimlenmiş; duygusal emek ile kişilik özellikleri arasındaki ilişkiler ise korelasyon ve regresyon analizleri ile tespit edilmiştir.

\section{Bulgular ve Tartışma}

Araştırmanın bu bölümünde öncelikle beş faktör kişilik modeline ve duygusal emek ölçeğine ilişkin boyutların ortalamaları ve birbirine göre farklılıkları değerlendirilirmiştir. Tablol'de beş faktör kişilik modeli ölçeğine ilişkin bulgular yer almaktadır: 
Tablo 1. Beş faktör kişilik modeli boyutlarının karşılaştırması

\begin{tabular}{|c|c|c|c|c|c|}
\hline Boyutlar & $\bar{x}$ & S.S & $\mathbf{F}$ & $\mathbf{p}$ & Karşılaştırma \\
\hline Dişadönüklük & 3,57 & 0,64 & \multirow{5}{*}{154,19} & \multirow{5}{*}{$\mathbf{0 , 0 0 0 * * *}$} & $\bar{a}$ \\
\hline Uyumluluk & 3,78 & 0,62 & & & $\mathrm{~b}$ \\
\hline Öz disiplin & 3,73 & 0,64 & & & $\mathrm{~b}$ \\
\hline Nevrotiklik & 2,87 & 0,58 & & & $\mathrm{c}$ \\
\hline Gelişime açıklık & 3,53 & 0,63 & & & $\mathrm{a}$ \\
\hline \multicolumn{6}{|c|}{$\begin{array}{l}\text { *** p<0,001 a,b,c: farklı harfleri içeren boyutlar arasında anlamlı farklılık vardır (p<0,05). } \\
\text { Tablo 1'de görüldüğ̈ gibi, otel çalışanlarının beş faktör kişilik modeline ilişkin } \\
\text { cevapları dişadönüklük ve gelişime açıklık boyutları ile uyumluluk ve öz disiplin } \\
\text { boyutlarında birbirine yakındır. Nevrotiklik boyutu ise düşük ortalamaya sahip olup bütün } \\
\text { boyutlardan farklıdır. Bu durum turizm sektörü için ele alındığında memnuniyet vericidir. } \\
\text { Daha önce de ifade edildiği üzere depresif, gergin, kaygıll, huzursuz, sabırsız ve üzgün olma } \\
\text { gibi durumları (Benet-Martinez ve John, 1998; Costa vd., 1991) açıklayan nevrotiklik } \\
\text { özelliği turizm sektöründe çalışma için uygun olmadığını ifade etmek mümkündür. Tablo } \\
\text { 2'de duygusal emek boyutlarının karşılaştırılmasına yer verilmiştir. }\end{array}$} \\
\hline
\end{tabular}

Tablo 2. Duygusal emek boyutlarının karşılaştırması

\begin{tabular}{lccccc}
\hline \multicolumn{1}{c}{ Boyutlar } & $\overline{\mathrm{X}}$ & s.s & $\mathbf{F}$ & $\mathbf{p}$ & Karşılaştırma \\
\hline Duygusal çelişki & 2,48 & 0,90 & \multirow{2}{*}{364,46} & $\mathbf{0 , 0 0 0 * * *}$ & $\mathrm{a}$ \\
Duygusal çaba & 3,67 & 0,91 & & $\mathrm{~b}$ \\
\hline
\end{tabular}

*** $\mathrm{p}<0,001 \mathrm{a}, \mathrm{b}$ : farklı harfleri içeren boyutlar arasında anlamlı farklılık vardır $(\mathrm{p}<0,05)$.

Tablo 2'den de anlaşılacağı üzere, otel çalışanlarının duygusal çaba gösterimleri, duygusal çelişki ortalamalarından fazla olup anlamlı bir farklılık göstermektedir. Daha önceki araştırmalarda (Keleş 2018), otel yöneticilerinin çalışanlarının derin davranışlarını/duygusal çabalarını arttırıcı önlemler alması gerekliliği de önerilmiştir. Araştırmada ortaya çıkan bu bulgu da turizm sektörü için uygun olarak değerlendirilen duygusal gösterimlerin, olmayanlara nzatan daha yüksek çıktığına işaret etmektedir. Duygusal Tablo 3'te beş faktör kişilik özellikleri ile duygusal emek gösterimleri arasındaki ilişkiyi betimleyen korelasyon matrisine yer verilmiştir.

Tablo 3. Duygusal emek ve kişilik özellikleri arasındaki ilişkiye ait korelasyon matrisi

\begin{tabular}{lllllllll}
\hline 1 & 2 & 3 & 4 & 5 & 6 & 7 \\
\hline
\end{tabular}

1. Dişadönüklük

2. Uyumluluk , 107

3. Öz disiplin $, 250 \quad, 595$

4. Nevrotiklik

5. Gelişime açıklık

6. Duygusal çelişki

$-, 409$

, 190

7. Duygusal çaba

$-, 139 *$

$$
\begin{gathered}
-, 235 \\
, 316 \\
-, 417 * * *
\end{gathered}
$$$$
-, 338
$$$$
\begin{array}{r}
, 277 \\
-, 402 * * *
\end{array}
$$$$
, 108
$$

, 037

,130*

,141*

, $130 *$

${ }^{* *} p<0,001 \quad{ }^{*} p<0,05$

Tablo 3, duygusal emek ile beş faktör kişilik özellikleri arasındaki korelasyonları göstermektedir. Buna göre, duygusal çelişki ile dışadönüklük ve nevrotiklik arasında düşük 
kuvvette anlamlı ilişkiler tespit edilmiştir. Duygusal çelişkinin dışadönüklük ile ilişkisi negatif yönlü iken, nevrotiklik ile ilişkisi pozitif yönlüdür. Duygusal çelişki ile uyumluluk ve öz disiplin arasında ise orta kuvvette negatif yönlü ilişkiler bulunmuştur. Gelişime açıklık boyutu ile duygusal çelişki arasında anlamlı bir ilişki bulunmamıştır. Duygusal çelişkiye ilişkin elde edilen bu bulgular; uyumluluk, özdisplin ve dışadönüklük özellikleri baskın oldukça duygusal çelişkinin azaldığ ; nevrotiklik arttıkça da duygusal çelişkinin arttığı şeklinde yorumlanabilir.

Duygusal emeğin duygusal çaba boyutu ile ilişkisine yönelik korelasyonlar, uyumluluk, özdisplin, nevrotiklik ve gelişime açıklığın duygusal çaba ile düşük kuvvette pozitif ilişkili olduğunu göstermektedir. Dışadönüklük ile duygusal çaba arasında ise anlamlı bir ilişki bulunmamıştır. Bu durum, dışadönüklük dışındaki bütün kişilik özelliklerinin, duygusal çaba sergileme eğilimini düşük de olsa arttırdığını göstermektedir. Söz konusu ilişkilerin yönünü ve kişilik özelliklerinin duygusal emek gösterme biçimlerini ne derece etkilediğini belirleyebilmek amacıyla gerçekleştirilen basit doğrusal regresyon analizi sonuçları Tablo 4'te ve Tablo 5'te verilmiştir.

Tablo 4. Kişilik özelliklerinin duygusal çelişki üzerindeki etkisine ilişkin basit doğrusal regresyon analizleri

\begin{tabular}{|c|c|c|c|c|c|c|c|}
\hline $\begin{array}{l}\text { Bağımlı } \\
\text { Değișken }\end{array}$ & $\begin{array}{l}\text { Bağımsız } \\
\text { Değişkenler }\end{array}$ & $\mathbf{b}_{\mathbf{j}}$ & $\mathbf{S}\left(\mathbf{b}_{\mathbf{j}}\right)$ & $\mathbf{t}$ & $\mathbf{p}$ & $\mathbf{R}^{2}$ & ANOVA \\
\hline \multirow{2}{*}{$\begin{array}{c}\text { Duygusal } \\
\text { Çelişki }\end{array}$} & Sabit & 2,882 & 0,255 & 11,288 & 0,000 & \multirow{2}{*}{0,004} & \multirow{2}{*}{$\begin{array}{l}F=2,583 \\
p=0,109\end{array}$} \\
\hline & Gelişime açıklık & $-0,114$ & 0,071 & $-1,617$ & 0,109 & & \\
\hline \multirow{2}{*}{$\begin{array}{c}\text { Duygusal } \\
\text { Çelişki }\end{array}$} & Sabit & 4,582 & 0,243 & 18,837 & 0,000 & \multirow{2}{*}{0,161} & \multirow{2}{*}{$\begin{array}{c}\mathrm{F}=76,982 \\
\mathrm{p}=0,000^{* * *}\end{array}$} \\
\hline & Özdisiplin & $-0,565$ & 0,064 & $-8,774$ & 0,000 & & \\
\hline \multirow{2}{*}{$\begin{array}{c}\text { Duygusal } \\
\text { Çelişki }\end{array}$} & Sabit & 3,167 & 0,250 & 12,691 & 0,000 & \multirow{2}{*}{0,019} & \multirow{2}{*}{$\begin{array}{c}\mathrm{F}=7,870 \\
\mathrm{p}=0,005^{* *}\end{array}$} \\
\hline & D1şadönüklük & $-0,193$ & 0,069 & $-2,805$ & 0,005 & & \\
\hline \multirow{2}{*}{$\begin{array}{l}\text { Duygusal } \\
\text { Çelişki }\end{array}$} & Sabit & 4,751 & 0,251 & 18,926 & 0,000 & \multirow{2}{*}{0,172} & \multirow{2}{*}{$\begin{array}{c}\mathrm{F}=84,177 \\
\mathrm{p}=0,000 * * *\end{array}$} \\
\hline & Uyumluluk & $-0,601$ & 0,066 & $-9,175$ & 0,000 & & \\
\hline \multirow{2}{*}{$\begin{array}{l}\text { Duygusal } \\
\text { Çelişki }\end{array}$} & Sabit & 1,274 & 0,218 & 5,833 & 0,000 & \multirow{2}{*}{0,073} & \multirow{2}{*}{$\begin{array}{c}\mathrm{F}=31,657 \\
\mathrm{p}=0,000 * * *\end{array}$} \\
\hline & Nevrotiklik & 0,420 & 0,075 & 5,626 & 0,000 & & \\
\hline
\end{tabular}

Tablo 4'teki bulgulara göre, bağımlı değişken (duygusal çelişki) ile bağımsız değiş̧kenler arasındaki ilişkilere yönelik oluşturulan basit doğrusal regresyon modellerinden, gelişime açıklık boyutunu oluşturan ilk model anlamlı değildir $(\mathrm{p}=0,109)$. Anlamlı olan basit doğrusal regresyon modelleri sırasıyla aşağıda verilmiştir:
Duygusal Çelişki $=4,582-0,565$ Özdisiplin
Duygusal Çelişki $=3,167$ - 0,193 Dişadönüklük
Duygusal Çelişki $=4,751-0,601$ Uyumluluk
Duygusal Çelişki $=2,882+0,420$ Nevrotiklik
$(\mathrm{F}=76,982 ; \mathrm{p}<0,001)$
$(\mathrm{F}=7,870 ; \mathrm{p}<0,01)$
$(\mathrm{F}=84,177 ; \mathrm{p}<0,001)$
$(\mathrm{F}=31,657 ; \mathrm{p}<0,001)$

Tablo 4'teki belirtme katsayıları $\left(\mathrm{R}^{2}\right)$, Otel çalışanlarının duygusal çelişki gösterimleri üzerindeki değişimlerinin her biri ayrı ayrı olmak üzere, $\% 16,1^{\prime}$ inin $\left(\mathrm{R}^{2}=0,161\right)$ özdisiplin özelliği kaynaklı azaldığı, \%1,9'unun $\left(\mathrm{R}^{2}=0,019\right)$ dışadönüklük özelliği kaynaklı azaldığı, \%17,2'sinin $\left(\mathrm{R}^{2}=0,172\right)$ uyumluluk kaynaklı azaldığ 1 ve $\% 7,3$ 'ünün $\left(\mathrm{R}^{2}=0,073\right)$ nevrotiklikten kaynaklanarak arttı̆̆ı değerlendirilebilir. Ortaya çıkan bu sonuçlar ilgili alanyazındaki çalışmalarla benzerlik göstermektedir (Basım vd., 2013; Begenirbaş ve Can 
Yalçın, 2012; Brotheridge ve Grandey 2002; Deniz, 2016; Gürsoy vd., 2011; Karatepe ve Aleshinloye, 2009; Liu vd., 2004; Spector vd, 2000). Bu bulgular, özdisiplin ve uyumluluk özellikleri yüksek olan çalışanların duygusal çelişkilerinin azalma eğiliminde olduğuna işaret etmektedir. Nevrotiklik ise duygusal çelişkiyi arttırmaktadır. Buna göre çalışanların istihdamında özdisiplin ve uyumluluk özellikleri yüksek bireylerin tercih edilmesi, nevrotik bireylerin ise tercih edilmemesi önerilebilir.

Tablo 5 incelendiğinde, bağımlı değişken (duygusal çaba) ile bağımsız değişkenler arasındaki ilişkilere yönelik oluşturulan basit doğrusal regresyon modellerinden, dışadönüklük boyutunu oluşturan model anlamlı değildir $(p=0,455)$. Kişiliğin diğer boyutları ile duygusal çaba arasında arasındaki modeller ise anlamlıdır $(\mathrm{p}<0,05)$.

Tablo 5. Kişilik özelliklerinin duygusal çelişki üzerindeki etkisine ilişkin basit doğrusal regresyon analizleri

\begin{tabular}{|c|c|c|c|c|c|c|c|}
\hline $\begin{array}{l}\text { Bağımlı } \\
\text { Değişken }\end{array}$ & $\begin{array}{l}\text { Bağımsız } \\
\text { Değişkenler }\end{array}$ & $\mathbf{b}_{\mathbf{j}}$ & $\mathbf{S}\left(\mathbf{b}_{\mathbf{j}}\right)$ & $\mathbf{t}$ & $\mathbf{p}$ & $\mathbf{R}^{2}$ & ANOVA \\
\hline \multirow{2}{*}{$\begin{array}{l}\text { Duygusal } \\
\text { Çaba }\end{array}$} & Sabit & 2,499 & 0,254 & 9,829 & 0,000 & \multirow{2}{*}{0,052} & \multirow{2}{*}{$\begin{array}{c}\mathrm{F}=22,018 \\
\mathrm{p}=0,000 * * *\end{array}$} \\
\hline & Gelişime açıklık & 0,332 & 0,071 & 4,692 & 0,000 & & \\
\hline \multirow{2}{*}{$\begin{array}{l}\text { Duygusal } \\
\text { Çaba }\end{array}$} & Sabit & 2,920 & 0,268 & 10,893 & 0,000 & \multirow{2}{*}{0,020} & \multirow{2}{*}{$\begin{array}{c}\mathrm{F}=8,139 \\
\mathrm{p}=0,005^{* *}\end{array}$} \\
\hline & Özdisiplin & 0,202 & 0,071 & 2,853 & 0,005 & & \\
\hline \multirow{2}{*}{$\begin{array}{l}\text { Duygusal } \\
\text { Çaba }\end{array}$} & Sabit & 3,484 & 0,257 & 13,573 & 0,000 & \multirow{2}{*}{0,001} & \multirow{2}{*}{$\begin{array}{l}F=0,559 \\
p=0,455\end{array}$} \\
\hline & Dışadönüklük & 0,053 & 0,071 & 0,748 & 0,455 & & \\
\hline \multirow{2}{*}{$\begin{array}{l}\text { Duygusal } \\
\text { Çaba }\end{array}$} & Sabit & 2,952 & 0,279 & 10,577 & 0,000 & \multirow{2}{*}{0,017} & \multirow{2}{*}{$\begin{array}{c}\mathrm{F}=6,848 \\
\mathrm{p}=0,009^{*} *\end{array}$} \\
\hline & Uyumluluk & 0,191 & 0,073 & 2,617 & 0,009 & & \\
\hline \multirow{2}{*}{$\begin{array}{l}\text { Duygusal } \\
\text { Çaba }\end{array}$} & Sabit & 3,064 & 0,229 & 13,371 & 0,000 & \multirow{2}{*}{0,018} & \multirow{2}{*}{$\begin{array}{c}\mathrm{F}=7,361 \\
\mathrm{p}=0,007 * *\end{array}$} \\
\hline & Nevrotiklik & 0,213 & 0,078 & 2,713 & 0,007 & & \\
\hline
\end{tabular}

Anlamlı olan basit doğrusal regresyon modelleri sırasıyla aşağıda verilmiştir: $\mathrm{p}<0,001)$

Duygusal Çaba $=2,499+0,332$ Gelişime Açılklı $\quad(\mathrm{F}=22,018$;
Duygusal Çaba $=2,920+0,202$ Özdisiplin
$(\mathrm{F}=8,139 ; \mathrm{p}<0,01)$
Duygusal Çaba $=2,952+0,191$ Uyumluluk
$(\mathrm{F}=6,848 ; \mathrm{p}<0,01)$
Duygusal Çaba $=3,064+0,213$ Nevrotiklik
$(\mathrm{F}=7,361 ; \mathrm{p}<0,01)$

Tablo 5 'teki belirtme katsayıları $\left(\mathrm{R}^{2}\right)$, otel çalışanlarının duygusal çaba gösterimleri üzerindeki değişimlerinin her biri ayrı ayrı olmak üzere, $\% 5,2$ 'sinin $\left(\mathrm{R}^{2}=0,052\right)$ gelişime açıklık boyutu, \%2'sinin $\left(\mathrm{R}^{2}=0,020\right)$ özdisiplin boyutu, \%1,7'sinin $\left(\mathrm{R}^{2}=0,017\right)$ uyumluluk boyutu ve \%1,8'inin $\left(\mathrm{R}^{2}=0,018\right)$ nevrotiklik boyutu kaynaklı arttığ şeklinde değerlendirilebilir. Ortaya çıkan bu sonuçlar, nevrotiklik boyutu hariç olmak üzere ilgili alanyazındaki çalışmalarla benzerlik göstermektedir (Kim, 2008; Sohn ve Lee, 2012). Nevrotikliğin küçük de olsa duygusal çabayı arttırması yönünde bu araştırmada ortaya çıkan bulgu, nevrotiklerin duygusal iniş çıkışlarından ve/veya turizm sektöründe çalışmanın verdiği zorunluluktan dolayı duygusal çabaya yöneldikleri şeklinde değerlendirilebilir. Her ne kadar kişilik özellikleri ile duygusal emeğin duygusal çaba boyutuna etkisi ortaya çıkmış olsa da, söz konusu etkinin duygusal çelişki kadar yüksek olmadığını söylemek yerinde olacaktır. 


\section{Sonuç ve Öneriler}

Turizm sektörü, yapısı gereği müşteriler ile yoğun iletişim gerektirmektedir. İletişimin niteliğini etkileyen çalışanların kişilik özellikleri ise bu noktada önem kazanmaktadır. Sektöre yönelik kişilik özelliğine sahip olmayan çalışanların, işletmenin bütün sistemini olumsuz etkilediği öne sürülmektedir (Pelit vd., 2010). Turizm sektöründe özellikle çalışanlardan beklenen hususlardan biri de, işletmelerin beklediği duygu gösterim kurallarının sergilenmesidir. Bu durumda da kişilik özellikleri ön plana çıkmaktadır.

Kişilik özelliklerinin duygusal emek gösterimleri ile ilişkilerin otel çalışanları üzerinde incelendiği bu araştırmada, özellikle özdisplin ve uyumluluk özellikleri öne çıkan çalışanların, duygusal emeğin duygusal çelişki boyutundaki davranışları daha az sergiledikleri; nevrotiklerin ise daha fazla duygusal çelişki yaşadıkları ortaya çıkmıştır. Bununla birlikte, duygusal emeğin duygusal çaba boyutundaki davranışlar, özdisiplin, uyumlu ve gelişime açıklık özellikleri yüksek olan bireyler tarafından daha fazla sergilenme eğilimindedir. Nevrotik kişiliğin duygusal çabayı arttırması yönünde ortaya çıkan sonuç ise, örneklem grubunun özellikleri ve/veya turizm sektörü ile açıklanmış olmasına rağmen üzerinde durulması gereken bir husustur. Her ne kadar söz konusu etki düşük çıkmış olsa da farklı örneklem gruplarında araştırmaya değerdir.

Turizmin önemli bir alanı olan otelcilik sektöründe müşteri ile çok fazla iletişim kurmayı gerektiren durumlar ortaya çıkmaktadır. Bu durumda örgütün belirlediği duygusal davranış kurallarına; başka bir ifade ile duygusal emek gösterimlerine, çalışanlar uymak zorundadır. Ancak çalışanların kişilik özellikleri duygusal emek gösterimine uygun değilse, örgütsel faktörlerin düzenlenmesi çok fazla önem arz etmeyecektir. Sonuç olarak turizm sektörüne uygun özdisiplin ve uyumluluk özelliği fazla olan bireylerin daha az, nevrotik bireylerin ise daha fazla duygusal çelişki yaşadıklarına yönelik bu araştırmada ortaya çıkan sonuçlar, çalışanların işe alınma sürecinde işe uygun kişilik özelliklerini taşıyan bireylerin tercih edilmesini gerekli kılmaktadır. İşe alım sürecinin yanı sıra, mevcut çalışanların özdisiplin ve uyumluluk özelliklerini geliştirecek, nevrotik özelliklerini ise mümkün olduğunca azaltmaya yönelik örgütsel faaliyetler tasarlanması, otel işletmelerinin çalışanlarından daha fazla verim elde etmesini sağlayacaktır.

\section{Kaynakça}

Aslan, Z. ve Sağlam Arı, G. (2018). "Kişilik Ve Duygusal Emek Arasındaki İlişkilerin Belirlenmesi Üzerine Bir Araştırma: Banka Çalışanları Örneği”. Pamukkale Üniversitesi Sosyal Bilimler Enstitüsü Dergisi, 30, 157-171.

Avc1, U., ve Boylu, Y. (2010). "Türk turizm çalışanları için duygusal emek ölçeği geçerlemesi." Seyahat ve Otel İşletmeciliği Dergisi, 7(2), 20-29.

Barrick, M. R. ve Mount, M. K. (2000). Select on Conscientiousness and Emotional Stability, Handbook of Principles of Organizational Behavior. 2. Bask1, United Kingdom, A John Wiley and Sons Ltd. Yayınları.

Barrick, M.R. ve Mount,M.K. (2003). "Meta-Analysis of the Relationship Between the Five Factor Model of Personality and Holland's Occupational Types," Personnel Psychology, $56,45-74$

Basım, N., Begenirbaş, M. ve Can Yalçın, R. (2013). "Effects of Teacher Personalities on Emotional Exhaustion: Mediating Role of Emotional Labor", Educational Sciences: Theory\&Practice, 13(3),1488-1496.

Begenirbaş, M. Ve Can Yalçın, R. (2012). “Öğretmenlerin Kişilik Özelliklerinin Duygusal Emek Gösterimlerine Etkileri.” Çag University Journal of Social Sciences, 9(1), 1-19 
Benet-Martínez, V. ve John, O.P. (1998). "Los Cinco Grandes Across Cultures and Ethnic Groups: Multitrait Multimethod Analysis of The Big Five in Spanish and English." Journal of Personality and Social Psychology, 75, 729-750

Brotheridge, C. M. ve Grandey, A. A. (2002). "Emotional Labor and Burnout: Comparing Two Perspectives of People Work". Journal of Vocational Behavior, 60 (1): 17-39.

Chu, K.H.L., ve Murrmann, S.K. (2006). "Development and validation of the hospitality emotional labor scale". Tourism Management, 27(6), 1181-1191.

Costa, P.T. ve McCrae, R.R.(1995). "Domains and Facets: Hiyerarchical Personality Assessment Using the Revised NEO Personality Inventory". Journal of Personality Assessment, 64(1), 21-50.

Costa, P.T., McCrae, R.R. ve Dye, D.A. (1991)." Facet Scales for Agreeableness and Conscientiousness; a Revision of the NEO Personality Inventory." Personality and Individual Differences, (12)9, 887-898.

Deniz, G. (2016). "Kişilik ve Sosyalizasyonun Duygusal Emek Üzerindeki Etkisi: Butik Otel Örneği." Anatolia: Turizm Araştırmaları Dergisi, 27 (2), 273 - 289.

Diefendorff, J.M, Croyle, M.H., ve Gosserand, R.H. (2005). "The Dimensionality and Antecedents of Emotional Labor Strategies". Journal of Organizational Behavior, 66, 339-357.

Doğan, T. (2013). "Beş Faktör Kişilik Özellikleri ve Öznel İyi Oluş.” Doğuş Üniversitesi Dergisi, 14(1), 56-64.

Eighie, B.O., Oguntuase, R.O., Ibode, F.O. ve Ehigie, R.I. (2012). "Personality Factors And Emotional Intelligence As Predictors Of Frontline Hotel Employees' Emotional Labour”. Global Advanced Research Journal Of Management And Business Studies, 1(9), 327-338.

Ellis, A., Abrams, M., ve Abrams, L. (2009). Personality Theories: Critical Perspectives. Thousand Oaks, CA: Sage.

Grandey, A. (2000)." Emotion regulation in the workplace: A new way to conceptualize emotional labor". Journal of Occupational Health Psychology, 5(1), 95-110.

Gürsoy, D., Boylu, Y., ve Avcı, U. (2011). "Identifying the Complex Relationships Among Emotional Labor and its Correlates". International Journal of Hospitality Management, 30(4), 783-794.

Hochschild, A.R. (2003). The managed heart: Commercialization of human feeling. Berkeley: University of California.

John, O. P., Donahue, E. M., ve Kentle, R. L. (1991). The Big-Five Inventory-Version 4a and 54. Berkeley, CA: Berkeley Institute of Personality and Social Research, University of California.

Judge, T. A., Woolf, E. F. ve Hurst, C. (2009). "Is Emotional Labor More Difficult For Some Than For Others? A Multilevel, Experience-Sampling Study". Personnel Psychology, 62(1): 57-88.

Karatepe, O. M. ve Aleshinloye, K. D. (2009). "Emotional Dissonance and Emotional Exhaustion among Hotel Employees in Nigeria". International Journal of Hospitality Management, 28 (3): 349-358.

Keleş, Y. (2018). "Otel Çalışanlarının Derin Davranışlarının Yaşadıkları İş-Aile ve Aile-İş̧ Çatışması Üzerindeki Etkisi." OPUS - Uluslararası Toplum Araştırmaları Dergisi, 16 (9), 575-599.

Keleş, Y. (2014). Örgütsel Adaletin Duygusal Emek Üzerindeki Etkisi: Antalya'daki Beş Yıldızlı Otel İşletmelerinde Bir Araştırma. (Yayınlanmamış Doktora Tezi). Gazi Üniversitesi Eğitim Bilimleri Enstitüsü, Ankara.

Keleş, Y. ve Tuna, M. (2018). "Turizm İşletmelerinde Duygusal Emek: Eleştirel Bir Yaklaşım.” Turizm Akademik Dergisi, 5 (2), 129-140. 
Kim, H.J. (2008). "Hotel Service Providers' Emotional Labor: The Antecedents and Effects on Burnout." International Journal of Hospitality Management, 27(2): 151-161.

Kruml, S.M. ve Geddes, D. (2000). "Exploring the Dimensions of Emotional Labor : The Heart of Hochschild's Work.” Management Communication Quarterly, 14 (1), 8-49.

Liu, Y., Perrewé, P. L., Hochwarter, W. A. ve Kacmar, C. J. (2004). "Dispositional Antecedents and Consequences of Emotional Labor at Work". Journal of Leadership \& Organizational Studies, 10(4): 12-25

McAdams, D.P. (2008). The person: An introduction to the science of personality psychology (5. Bask1). New Jersey: Wiley

McCrae, R.R. ve Costa, P.T. (1987). "Validation of the five-factor model of personality across instruments and observers." Journal of Personality and Social Psychology, 52(1), 81-90.

McCrae, R.R. ve Costa, P. (1991) “ Adding Liebe und Arbeit: The Full Five-Factor Model and Well-Being”. Personality and Social Psychology Bulletin, 17(2), 227-232.

Morris, J.A., ve Feldman D.C. (1996). "The dimensions, antecedents, and consequences of emotional labor." Academy of Management Review, 21, 986-1010.

Pelit, E., Türkmen, F. ve Yarmac1, N. (2010). "Turizm Sektöründeki İşgörenlerin Kişilik Özelliklerini Değerlendirmeye Yönelik Bir Araştırma”. Sosyal ve Beşeri Bilimler Dergisi, 2(1), 9-16.

Robbins, S.P., DeCenzo, D.A. ve Coulter, M. (2013). Fundementals of Management. UK: Pearson.

Schultz, D.P. ve Schultz, S.E. (2009). Theories of Personality. Wadsworth Publishing.

Sekerka, L.E. ve Fredrickson, B. L. (2010). Working positively toward transformative cooperation. P.Alex Linley, Susan Harrington, \& Nicola Garcea (Ed.), içinde Oxford handbook of positive psychology and work, (ss. 81-94). New York: Oxford University Press.

Sohn, H.-K., ve Lee, T.J. (2012). "Relationship Between HEXACO Personality Factors and Emotional Labour of Service Providers in the Tourism Industry." Tourism Management, 33, 116-125.

Somer, O., Korkmaz, M. ve Tatar, A. (2002). "Beş Faktör Kişilik Envanterinin Geliştirilmesi-1: Ölçek ve Alt Ölçeklerin Oluşturulması". Türk Psikoloji Dergisi, 17(49), 21-33.

Spector, P.E., Zapf, D., Chen, P.Y. ve Frese, M. (2000). "Why Negative Affectivity Should Not Be Controlled in Job Stress Research: Don't Throw Out the Baby with the Bath Water". Journal of Organizational Behavior, 21(1): 79-95

Tan, H.H., Foo, M.D., Chong, C.L. ve Renee, N.G. (2003). "Situational And Dispositional Predictors Of Displays Of Positive Emotions". Journal Of Organizational Behavior, 24,961-978.

Vecchio, R. P. (1991). Organizational behavior. USA: The Dryden.

Smith, E.E., Nolen-Hoeksema, S., Fredricson, B., Loftus, G.R., Bem, D.J. ve Maren, S. (2012). Introduction to psychology (14. Bask1). Ankara: Arkadaş Yayınları.

Watson, D. ve Clark, L.A. (1997). Extraversion and its positive emotional core. R. Hogan, S. Briggs ve J.Johnson (Ed.). Handbook of personality psychology içinde (s.767-793). San Diego: Academic Press. 